OPEN ACCESS

ISSN 25482254 (online)

ISSN 20893833 (print)

Edited by:

Mahardika Darmawan Kusuma Wardana

Reviewed by:

Deni Adi Putra

${ }^{*}$ Correspondence:

Asri Fauzi

asrifauzi@unram.ac.id

Received: 11 November 2021 Accepted: 15 November 2021 Published: 18 November 2021

Citation:

Ermianal, Rosyidah ANK, Fauzi

A, Hidayati VR (2021)

Effectiveness of Web-Based

Flipped Classroom Reviewed

from Understanding

Mathematics Concepts of

Primary Teacher Education

Students.

Pedagogia: Jurnal Pendidikan. 11:1.

doi: 10.21070/pedagogia.v11i1.1464

\section{Effectiveness of Web-Based Flipped Classroom Reviewed from Understanding Mathematics Concepts of Primary Teacher Education Students}

\section{Efektivitas Flipped Classroom Berbasis Web Ditinjau dari Pemahaman Konsep Matematika Mahasiswa Pendidikan Guru Sekolah Dasar}

\author{
Ida Ermiana' ${ }^{1}$ Awal Nur Khalifatur Rosyidah ${ }^{2}$, Asri Fauzi ${ }^{3 *}$, Vivi Rachmatul Hidayati ${ }^{4}$ \\ Universitas Mataram, Indonesia
}

This study aims to determine the effectiveness of the web-based Flipped Classroom model in terms of understanding the mathematical concepts of PGSD students. This type of research is a quasi-experimental quantitative research with one group pretestposttest. This research was conducted on 2nd-semester PGSD students taking Mathematics Education courses. The population of this study was all 2nd-semester PGSD students and the sample of this study was taken randomly as many as 32 students. This research instrument uses a test for understanding mathematical concepts on geometry material with a total of 10 multiple-choice questions. The data analysis techniques in this study are the normality test as a prerequisite test, the Wilcoxon test to determine the difference between the average pretest and posttest, and the effect size test (Cohen's d) to conclude that the web-based flipped classroom model is effective or not on understanding mathematical concepts. The results of this study indicate that the normality test on the pretest data obtained data with a normal distribution, but on the posttest data the data was not normally distributed, so the Wilcoxon nonparametric test was used. Wilcoxon test results show the results of sig. $<0.005$, which means that there is a significant average difference between the pretest and post-test scores. Then from the results of the Effect Size test, the results of 1.55 are included in the very large category. This means that the effectiveness of the application of the flipped classroom model is very large for understanding the concept. From the research results, it can be concluded that the application of web-based Flipped Classrooms is effective in terms of understanding students' mathematical concepts.

Keywords: Flipped Classroom, Concept Understanding, Students 
Penelitian ini bertujuan untuk mengetahui efektivitas model Flipped Classroom berbasis web ditinjau dari pemahaman konsep matematika mahasiswa PGSD. Jenis penelitian ini merupakan penelitian kuantitatif quasy experiment dengan one group pretest posttest. Penelitian ini dilaksanakan pada mahasiswa PGSD semester 2 yang menempuh mata kuliah Pendidikan matematika. Populasi penelitian ini adalah seluruh mahasiswa PGSD semester 2 dan sampel penelitian ini diambil secara acak sebanyak 32 mahasiswa. Instrumen penelitian ini menggunakan soal tes pemahaman konsep matematika pada materi geometri dengan jumlah 10 soal pilihan ganda. Teknik analisis data pada penelitian ini yaitu uji normalitas sebagai uji prsayarat, uji Wilcoxon untuk mengetahui perbedaan rata-rata pretest dan posttest, dan uji effect size (Cohen's d) untuk menarik kesimpulan model flipped classroom berbasis web efektif atau tidak terhadap pemahaman konsep matematika. Hasil penelitian ini menunjukkan bahwa uji normalitas pada data pretest didapatkan data berdistribusi normal, tetapi pada data posttest data tidak berdistribusi normal, sehingga menggunakan uji nonparametric Wilcoxon. Hasil uji Wilcoxon menunjukkan hasil sig. $<0,05$ yang artinya terdapat perbedaan rata-rata yang signifikan antara nilai pre-test dan post-test. Kemudian dari hasil uji Effect Size menunjukkan hasil 1,55 termasuk ke dalam kategori sangat besar. Hal ini efektivitas penerapan model flipped classroom sangat besar terhadap pemahaman konsep. Dari hasi penelitian dapat disimpulkan bahwa penerapan Flipped Classroom berbasis web efektif ditinjau dari pemahaman konsep matematika mahasisa.

Kata Kunci: Flipped Classroom; Pemahaman Konsep, Mahasiswa, 


\section{PENDAHULUAN}

Pandemi covid 19 yang melanda ini menuntut dosen agar lebih kreatif dan inovatif memaksimalkan proses perkuliahan. Perkuliahan yang dilaksanakan secara online atau berbasis daring dengan menggunakan berbagai platform diharapkan dapat menjadi solusi dalam perkuliahan. Tatap maya selama pandemi salah satunya menggunakan platform web moodle yang disediakan oleh Universitas. Efektivitas dari teknologi seluler seperti aplikasi komputer dapat memudahkan akses ke berbagai platform dalam pembelajaran online dan memfasilitasi pembelajaran dengan maksimal sehingga dapat merancang lingkungan belajar yang aktif walaupun dalam kondisi yang terbatas Nkomo et al., (2021); Panigrahi et al., (2018). Pelibatan mahasiswa secara aktif dalam proses pembelajaran diharapkan memberikan pengaruh yang baik pada kemampuan pemahaman konsep dan pemahaman prosedural, karena dengan menemukan, mengeksplor konsep diharapkan dapat meningkatkan penguasaan mahasiswa. Keterlibatan siswa dianggap sebagai faktor penting dalam mendukung pembelajaran dan pengembangan siswa. Kahu (2013) Pemahaman konsep merupakan hal mendasar yang harus dimiliki oleh peserta didik dikarenakan segala sesuatu yang bersifat procedural dan lebih kompleks harus memiliki dasar yang kuat yakni pemahaman konsep.

Pemahaman konsep dapat digunakan untuk menyelesaikan suatu permasalahan yang berkaitan dengan konsep yang dimiliki. Menghubungkan konsep dengan konsep lainnya merupakan sebuah keharusan yang dilakukan dalam proses penyelesaian permasalahan. Sanjaya (2009) Seperti yang di ungkapkan oleh Ermiana et al., (2020) bahwa pada pendidikan tinggi khususnya pada mahasiswa PGSD, pemahaman konsep matematika hendaknya dikuasai oleh mahasiswa dengan baik. Hal ini di karenakan mahasiswa PGSD yang nantinya akan menjadi guru SD harus memiliki pengetahuan mendasar yang baik sehingga konsep yang akan disampaikan pada siswa tidak salah atau keliru.Salah satu model yang digunakan agar mahasiswa dapat belajar lebih optimal walaupun dengan jarak jauh adalah model flipped classroom berbasis web.

Model pembelajaran Flipped Classroom adalah salah satu upaya untuk memberi solusi permasalahan pemahaman konsep matematika yang dapat diterapkan dalam melaksanakan pembelajaran jarak jauh selama pandemi. Pada dasarnya, konsep model pembelajaran Flipped Classroom yaitu mahasiswa di rumah mengerjakan apa yang dilakukan di kelas yaitu belajar dengan memahami materi yang telah diberikan oleh dosen, dan di kelas mahasiswa mengerjakan apa yang biasanya dikerjakan siswa di rumah yaitu mngerjakan soal dan menyelesaikan masalah. Xiao et al., (2021); Zhang \& Feng (2019); Maolidah et al., (2017). Flipped Classroom merupakan suatu cara dalam proses pembelajaran yang mengurangi kapasitas kegiatan pembelajaran di dalam kelas dengan memaksimalkan interaksi satu sama lain yaitu guru, siswa dan lingkungannya. Model pembelajaran Flipped Classroom ini memanfaatkan media pembelajaran yang dapat diakses secara online oleh siswa yang mampu mendukung materi pembelajarannya. Kazu \& Kurtoğlu (2020); Ulya et al., (2019)
Flipped Classroom merupakan model pembelajaran membalik kondisi kelas konvensional, di mana mahasiswa dapat menonton materi kuliah melalui video ceramah atau vodcast sebelum datang ke kelas, kemudian menghabiskan waktu kelas untuk kegiatan belajar lainnya. Unal et al., (2021); Inayah et al., (2021). Sejalan dengan yang dikatakan oleh Fung et al., (2021) bahwa pembelajaran flipped classroom ini merupakan metode yang dapat mengurangi kapasitas kegiatan di dalam kelas dengan memaksimalkan interaksi satu sama lain. Flipped classroom merupakan bentuk pembelajaran blended yang menggabungkan pembelajaran sinkron (synchronous) dengan pembelajaran mandiri (asynchronous). Pembelajaran sinkron biasanya terjadi di kelas dimana peserta didik berinteraksi dengan pendidik dan teman sekelas serta dapat menerima umpan balik pada saat yang sama. Sedangkan pembelajaran asinkron sifatnya lebih mandiri. Bergmann \& Sams (2012); McLaughlin et al., (2014)

Beberapa manfaat atau keunggulan metode ini dapat membantu peserta didik lebih berperan aktif dalam mencari dan mengolah belajarnya sendiri. Adapun keunggulan flipped classroom yang dijabarkan oleh Cho et al., (2021) yaitu 1) model flipping dapat menjawab tantangan peserta didik masa kini; 2) membantu peserta didik yang memiliki banyak kegiatan di luar sekolah; 3) membantu peserta didik yang berkeinginan dan berusaha untuk memahami materi belajar; 4) membantu peserta didik untuk menjadi yang terbaik; 5) memungkinkan pendidik memahami karakteristik peserta didik yang lebih baik; 6) meningkatkan interaksi antar peserta didik.

Kegiatan pada metode flipped classroom dibagi menjadi tiga kegiata yaitu, sebelum kelas dimulai (pre-class), saat kelas dimulai (in class), dan setelah kelas berakhir (out of class) Veres \& Muntean (2021). Pada penelitian ini, kegiatan pertama seblum kelas dimulai, mahasiswa sudah mempelajari materi yang akan dibahas. Materi dapat diakses melalui web moodle yang sudah disiapkan oleh peneliti, dalam tahap ini kemampuan yang diharapkan dapat dimiliki mahasiswa yaitu mengingat, memahami materi. Kemudian pada kegiatan saat kelas dimulai mahasiswa dapat mengaplikasikan dan menganalisis materi melalui kegiatan diskusi dikelas dimana kelas yang digunakan menggunakan web meeting sehingga tercipta diskusi yang aktif antar mahasiswa. Selanjutnya pada tahap terakhir setelah kelas berakhir, diharapkan mahasiswa dapat menyimpulkan apa yang sudah dipelajari dan dilanjutkan dengan mengerjakan tugas yang sudah disediakan di dalam web.

Berdasarkan pemaparan di atas, metode flipped classroom ini dapat digunakan dalam perkuliahan untuk membantu mahasiswa cepat dan bisa memahami konsep matematika. Flipped classroom berbasis web ini digunakan untuk menunjang pelaksanaan perkuliahan yang tentunya diharapkan dapat membantu pemahaman konsep matematika mahasiswa. Berdasarkan pemaparan diatas maka tujuan dari penelitian ini adalah dapat diketahui efektivitas flipped classroom berbasis web yang digunakan mahasiswa ditinjau dari pemahaman konsep matematika mahasiswa pendidikan guru sekolah dasar (PGSD).

\section{METODE}

Penelitian ini merupakan penelitian kuantitatif dengan model 
quasy experimental design. Tipe eksperimen yang digunakan adalah one group pretest posttest design. Penggunaan tipe ini karena dalam penelitian ini hanya satu kelas yang diteliti sehingga data diambil sebelum dan sesudah diberikan perlakuan pada subjek yang sama. Desain penelitian yang digunakan dalam penelitian ini sebagai berikut;

\section{[Figure 1 about here.]}

Tahapan dalam penelitian ini yaitu pemberian pretest kepada mahasiswa, kemudian dilanjutkan dengan memberikan perlakuan Flipped Classroom berbasis web, dan tahap terakhir setelah perlakuan mahasiswa diberikan posttest untuk mengetahui kemampuan mahasiswa setelah perlakuan. Populasi penelitian ini adalah seluruh mahasiswa PGSD Universitas Mataram. Kemudian teknik pengambilan sampel menggunakan teknik Simple Random Sampling dimana pada pengambilan anggota sampel dari populasi yang dilakukan secara acak tanpa memperhatikan strata yang ada dalam populasi itu. Berdasarkan hal tersebut yang menjadi sampel pada penelitian ini adalah mahasiswa PGSD Universitas Mataram sebanyak 32 mahasiswa yang diambil dari semester 2. Mahasiswa semester 2 dijadikan sampel dengan pertimbangan bahwa pada semester 2 terdapat mata kuliah Pendidikan matematika SD sehingga memudahkan peneliti untuk melakukan penelitian.

Instrumen utama penelitian ini menggunakan soal tes pemahaman konsep matematika. Bentuk tes yang digunakan adalah bentuk pilihan ganda sebanyak 10 soal yang mewakili indicator pemahaman konsep matematika. Beberapa indicator pemahaman konsep yang digunakan dalam penelitian ini yaitu: 1) mampu menerangkan secara verbal mengenai apa yang telah dicapainya; 2) mampu menyajikan situasi matematika ke dalam berbagai cara serta mengetahui perbedaan; 3) mampu menerapkan hubungan antara konsep dan prosedur; 4) mampu menerapkan konsep secara algoritam; dan 5) mampu mengembangkan konsep yang telah dipelajari.

Teknik analisis data pada penelitian ini menggunakan beberapa uji statistik yaitu uji normalitas yang bertujuan untuk mengetahui apakah data berasal dari populasi yang berdistribusi normal atau tidak. Pengujian hipotesis menggunakan IBM SPSS Statistic dengan uji KolmogrovSmirnov. Kriteria keputusannya, jika sig. > 0,05 maka data berdistribusi normal dan sebaliknya jika sig. $<0,05$ maka data tidak berdistribusi normal. Setelah dilakukan uji normalitas maka dilakukan uji lanjutan. Uji lanjutan ini dilakukan berdasarkan hasil uji prasyarat yaitu uji normalitas. Jika data yang diperoleh berasal dari data yang berdistribusi normal maka dilakukan uji t berpasangan. Sedangkan jika uji normalitasnya menunjukkan data tidak berdistribusi normal maka dilakukan uji non parametrik dengan uji Wilcoxon. Uji t berpasangan dan uji Wilcoxon merupakan uji lanjutan untuk mengetahui apakah terdapat perbedaan rata-rata hasil pretest dan posttes. Selanjutnya setelah mengetahui adanya perbedaan rata-rata pretest dengan posttest, maka dilanjutkan uji efektivitas.

Jika data berdistribusi normal maka uji efektivitas menggunakan uji statistic N-Gain. Sedangkan jika data tidak berdistribusi normal maka uji efektivitasnya menggunakn uji effect size (Cohen's d) . Thalheimer \& Cook (2002). Berikut ini adalah cara menhgitung effect size (Cohen's d).

$$
d=\frac{\bar{x}_{t}-\bar{x}_{c}}{s_{\text {pooled }}}
$$

dengan

$$
s_{\text {pooled }}=\sqrt{\frac{\left(n_{t}-1\right) s_{t}{ }^{2}+\left(n_{c}-1\right) s_{c}{ }^{2}}{n_{t}+n_{c}}}
$$

keterangan:

$\mathrm{d}=$ effect size Cohen

$\bar{x}=$ mean

$\mathrm{s}=$ standard deviation

$\mathrm{n}=$ jumlah subjek

Subscript $t$ (st) artinya untuk kelas yang mendapatkan treatment (dalam penelitian ini adalah nilai post-test).

Subscript c (sc) artinya untuk kelas kontrol (dalam penelitian ini adalah nilai pre-test).

\section{HASIL DAN PEMBAHASAN}

\section{Hasil Penelitian}

Pengumpulan data dalam bentuk tes telah dilaksanakan pada sampel penelitian. Terdapat 32 subjek pada sampel penelitian. Penelitian ini didesain dengan jenis quasi-experiment dengan teknik pengambilan sampel dengan purposive-random sampling. Data berupa skor pre-test dan post-test. Pengolahan dan analisis data dilakukan dengan bantuan aplikasi SPSS 23. Uji hipotesis dilakukan dengan uji-t berpasangan yang akan dilakukan uji normalitas terlebih dahulu sebagai uji prasyarat. Berikut ini adalah hasil uji normalitas dari masing-masing nilai.

\section{[Table 1 about here.]}

Berdasarkan tabel di atas terdapat 3 kategori hasil uji Wilcoxon yaitu negative ranks, positive ranks, dan ties. Kategori negative ranks maksudnya adalah mahasiswa yang memperoleh nilai pre-test lebih besar dibandingkan nilai posttest. Jumlah mahasiswa yang berada pada kategori ini sebanyak 1 mahasiswa. Kemudian kategori kedua yaitu positive ranks dimana nilai pre-test mahasiswa lebih kecil dibandingkan nilai post-test. Jumlah mahasiswa pada kategori positive ranks ini sebanyak 27 mahasiswa. Dan kategori terakhir yaitu ties dimana nilai pre-test dan post-testnya sama. Jumlah mahasiswa pada kategori ini sebanyak 4 mahasiswa. Selanjutnya untuk melihat perbedaan rata-rata antara pre-test dan post-test dilihat dari hasil signifikan Wilcoxon. Hasil uji Wilcoxon dapat dilihat pada tabel di bawah.

\section{[Table 2 about here.]}

Berdasarkan Tabel 3., Sig. pada hasil uji Wilcoxon adalah 0.000 yang itu kurang dari 0.05. Berdasarkan hasil tersebut, dapat ditarik kesimpulan bahwa terdapat perbedaan rata-rata yang signifikan antara nilai pre-test dan post-test pada materi geometri bangun datar yang diantaranya diimplementasikan pembelajaran model flipped classroom.

Setelah didapatkan kesimpulan bahwa terdapat perbedaan 
rata-rata yang signifikan, dilakukan perhitungan effect size untuk mengetahui efektivitas dari model pembelajaran (flipped classroom) yang sudah diimplementasikan dalam perkuliahan. Effect Size dimasudkan untuk mengukur hubungan atau efektivitas antara dua variable yang ada pada satu populasi. Kelley \& Preacher (2012). Effect size dapat digunakan untuk melihat efektivitas suatu perlakuan (treatment) yang dilakukan pada suatu kelompok sampel. Singkatnya, effect size dapat memberikan nilai efektivitas suatu treatment (Rosenthal, 1994). Kemudian dilakukan perhitungan dengan bantuan Microsoft Excel, didapatkan effect size Cohen adalah 1,55. Berdasarkan Sawilowsky (2009) nilai $\mathrm{d}=1.55$ termasuk ke dalam kategori sangat besar (very large). Hal ini efektivitas dari pengimplementasian model flipped classroom sangat besar terhadap pemahaman konsep geometri bangun datar mahasiswa.

\section{Pembahasan}

Berdasarkan penelitian yang sudah dilakukan menunjukkan bahwa penerapan pembelajaran Flipped Classroom berbasi web dapat dikatakan efektif ditinjau dari pemahaman konsep mahasiswa. Hal ini dibuktikan dengan adanya perbedaan rata-rata yang signifikan antara hasil pretest dengan posttest setelah dilakukan perlakuan pembelajaran Flipped Classroom berbasis web. Penelitian relevan yang dilakukan oleh Yanah et al., (2018); Saputra \& Mujib (2018) bahwa penggunaan Flipped Classroom efektif terhadap penguatan dan penguasaan pemahaman konsep matematika siswa.

Meningkatnya pemahaman konsep matematika dikarenakan pada pembelajaran flipped classroom tersebut menuntut mahasiswa akan lebih banyak belajar secara mandiri. Sejalan dengan yang dikatakan Fedistia \& Musdi (2020) salah satu keunggulan dari model flipped classroom adalah peserta didik lebih mandiri dalam mempelajari materi pelajaran dan peserta didik juga dapat belajar secara fleksibel sesuai dengan situasi dan kondisi yang nyaman. Meningkatnya kemandirian belajar peserta didik maka akan meningkat juga pemahaman dan hasil belajar mahasiswa. Fauzi \& Widjajanti (2018); Rahmatih et al., (2020).

Pembelajaran flipped classroom dipusatkan kepada peserta didik dimana model pembelajaran ini menerapkan konsep terbalik yaitu kegiatan yang secara konvensional dilakukan dikelas menjadi kegiatan di rumah. Model pembelajaran ini membantu peserta didik bertanggung jawab untuk memecahkan persoalan pemahaman yang diberikan sehingga peserta didik menjadi pembelajar yang aktif Oktarina et al., (2020). Model pembelajaran flipped classroom ini tidak hanya berpengaruh kepada peserta didik, melainkan juga dapat mempengaruhi pemahaman konsep mahasiswa. Pemahaman konsep mahasiswa pada mata kuliah Pendidikan matematika lebih tinggi dibandingkan sebelum menggunakan model pembelajaran tersebut. Hal ini dikarenakan proses pembelajaran mahasiswa lebih banyak memiliki kesempatan untuk mengingat kembali konsep yang telah dipelajari. Model pembelajaran flipped classroom ini membuat mahasiswa memiliki waktu belajar yang lebih banyak dan dapat menyesuaikan waktu belajar serta kecepatan dalam memahami apa yang dipelajarinya. Oktarina et al., (2020); Hidayah \& Sumbawati (2019); Kurniawan et al., (2020). Penelitian ini juga mengacu pada teori belajar yang mendukung model Flipped Classroom yaitu teori belajar Konstruktivisme. Teori belajar konstruktivisme ini bersifat generative dimana siswa akan menciptakan sendiri suatu makna/pengetahuan dari apa yang telah dipelajari. Maksudnya seseorang akan membina pengetahuan dirinya secara aktif dengan cara membandingkan informasi atau pengetahuan yang baru didapat dengan pengetahuan yang sebelumnya dipelajari. Yanah et al., (2018); Rokhmania \& Kustijono (2017).

Pada saat menggunakan model Flipped Classroom berbasis web pada pembelajaran, mahasiswa akan membangun pengetahuannya sendiri yang berasal dari pengetahuan awal diperolehnya melalui bahan ajar yang sudah diupload pada situs pembelajaran daring unram yang sudah disiapkan oleh dosen. Pada bahan ajar tersebut disajikan fenomena-fenomena dan beberapa pertanyaan yang harus dijawab mengenai materi yang akan dibahas pada kegiatan pembelajaran melalui web meeting. Selanjutnya, saat pembelajaran menggunakan web meeting, mahasiswa akan membandingkan pengetahuan yang dimilikinya dengan pengetahuan yang baru sehingga merangsang mahasiswa untuk berpikir kritis dan kreatif dalam memahami konsep untuk pemecahan masalah matematika.

\section{KESIMPULAN}

Berdasarkan hasil penelitian dan pembahasan, dapat disimpulkan bahwa model Flipped Classroom berbasis web efektif digunakan untuk meningkatkan pemahaman konsep matematika mahasiswa. Hal ini dibuktikan dari hasil uji statistic Wilcoxon dimana terdapat perbedaan rata-rata yang signifikan antara pretest dengan posttest. Selanjutnya berdasarkan uji Effect Size Cohen didapatkan hasil sebesar 1,55. Hasil tersebut termasuk kategori sangat besar (very large). Artinya bahwa efektivitas dari pengimplementasian model flipped classroom berbasis web sangat besar terhadap pemahaman konsep matematika mahasiswa. Saran yang dapat diberikan dari hasil pengamatan secara langsung saat proses pembelajaran dan analisis data, maka peneliti memberikan saran yaitu: model pembelajaran Flipped Classroom dapat digunakan sebagai alternatif bagi pendidik untuk menciptakan kegiatan pembelajaran yang interaktif pada masa pandemic covid-19 saat ini agar hasil belajar yang dihasilkan sesuai dengan target dan tujuan pembelajaran yang dirumuskan.

\section{UCAPAN TERIMA KASIH}

Ucapan terima kasih kepada tim peneliti dan semua yang terlibat dalam penelitian ini yang sudah membantu menyelesaikan penelitian ini. Selanjutnya ucapan terima kasih pula kepada Universitas Mataran khususnya Fakultas Keguruan dan Ilmu Pendidikan yang sudah mendanai penelitian PNBP ini sehingga dapat terlaksana dengan lancar. 


\section{REFERENCES}

Ardiana, N. A., Pardimin, P., \& Wijayanto, Z. (2020). Eksperimentasi Model Pembelajaran Flipped Classroom Ditinjau dari Disposisi Matematis Siswa. UNION: Jurnal Ilmiah Pendidikan Matematika, 8(1), 97. https://doi.org/10.30738/union.v8i1.7612

Bergmann, J., \& Sams, A. (2012). Flip your classroom: talk to every student in every class every day. In International Society for Technology in Education. Iste.

Cho, H. J., Zhao, K., Lee, C. R., Runshe, D., \& Krousgrill, C. (2021). Active learning through flipped classroom in mechanical engineering: improving students' perception of learning and performance. International Journal of STEM Education, 8(1), 1-13. https://doi.org/10.1186/s40594-021-00302-2

Ermiana, I., Karma, I. N., \& Affandi, L. H. (2020). The Effectiveness of Multimedia-Based Learning on Students' Concept Understanding at Grade 4 Elementary School in Kediri District. ATLANTIS PRESS: Proceedings of the 1st Annual Conference on Education and Social Sciences (ACCESS 2019), 465(Access 2019), 238-241. https://doi.org/10.2991/assehr.k.200827.060

Fauzi, A., \& Widjajanti, D. B. (2018). Self-regulated learning: The effect on student's mathematics achievement. Journal of Physics: Conference Series, 1097(1). https://doi.org/10.1088/1742-6596/1097/1/012139

Fedistia, R., \& Musdi, E. (2020). Efektivitas Perangkat Pembelajaran Berbasis Flipped Classroom untuk Meningkatkan Kemampuan Penalaran Matematis Peserta Didik. Jurnal Didaktik Matematika, 7(1), 45-59. https://doi.org/10.24815/jdm.v7i1.14371

Fung, C. H., Besser, M., \& Poon, K. K. (2021). Systematic Literature Review of Flipped Classroom in Mathematics. Eurasia Journal of Mathematics, Science and Technology Education, 17(6), 1-17. https://doi.org/10.29333/ejmste/10900

Hidayah, N., \& Sumbawati, M. S. (2019). Efektivitas Model Pembelajaran Flipped Classroom terhadap Self Regulated Learning dan Hasil Belajar Siswa pada Mata Pelajaran Dasar Desain Grafis di SMK N 1 Surabaya. Jurnal ITEdu, 04(01), 165-173.

Inayah, S., Septian, A., \& Ramadhanty, C. L. (2021). The development of flipped classroom model learning device based on problem based learning to improve critival thinking ability and self-regulated learning. Icconects, 200-205.

Kahu, E. R. (2013). Framing student engagement in higher education. Studies in Higher Education, 38(5), 758-773. https://doi.org/10.1080/03075079.2011.598505

Kelley, K., \& Preacher, K. J. (2012). On effect size. Psychological Methods, 17(2), 137-152. https://doi.org/10.1037/a0028086

Maolidah, I. S., Ruhimat, T., \& Dewi, L. (2017). Efektivitas Penerapan Model Pembelajaran Flipped CLASSROOM PADA PENINGKATAN KEMAMPUAN BERPIKIR KRITIS SISWA. Edutcehnologia, 3(2), 160170.

McLaughlin, J. E., Roth, M. T., Glatt, D. M., Gharkholonarehe, N., Davidson, C. A., Griffin, L. M., Esserman, D. A., \& Mumper, R. J. (2014). The flipped classroom: A course redesign to foster learning and engagement in a health professions school. Academic Medicine, 89(2), 236-243. https://doi.org/10.1097/ACM.0000000000000086

Nkomo, L. M., Daniel, B. K., \& Butson, R. J. (2021). Synthesis of student engagement with digital technologies: a systematic review of the literature. International Journal of Educational Technology in Higher Education, 18(1), 1-26. https://doi.org/10.1186/s41239-021-00270-1

Oktarina, R., Ambiyar, \& Fhadillah. (2020). Efektivitas Komunikasi Dua Arah Pada Blended Learning Berorientasi Flipped Classroom Pada Masa New Normal Covid 19. Media Bahasa, Sastra, Dan Budaya Wahana, 26(2013), 483-492. https://journal.unpak.ac.id/index.php/wahana/article/view/2771

Panigrahi, R., Srivastava, P. R., \& Sharma, D. (2018). International Journal of Information Management Online learning: Adoption, continuance , and learning outcome - A review of literature. International Journal of Information Management, 43(2018), 1-14.
https://www.sciencedirect.com/science/article/pii/S0268401216304662?via\%3 Dihub\%0Ahttps://doi.org/10.1016/j.ijinfomgt.2018.05.005

Rahmatih, A. N., Fauzi, A., \& Ermiana, I. (2020). Hubungan Motivasi dan Kemandirian Belajar Mahasiswa Calon Guru Sekolah Dasar. Wahana Sekolah Dasar, 28(2), 76-83. https://doi.org/10.17977/um035v28i22020p076

Rokhmania, F. T., \& Kustijono, R. (2017). Efektivitas penggunaan E-Modul berbasis flipped classroom untuk melatih keterampilan berpikir kritis. Seminar Nasional Fisika, November, 91-96.

Rosenthal, R. (1994). Parametric measures of effect size. In The handbook of research synthesis (pp. 231-244). Russell Sage Foundation.

Sanjaya, W. (2009). Strategi Pembelajaran Berorientasi Standar Proses Pendidikan. Kencana.

Saputra, M. E. A., \& Mujib, M. (2018). Efektivitas Model Flipped Classroom Menggunakan Video Pembelajaran Matematika terhadap Pemahaman Konsep. Desimal: Jurnal Matematika, 1(2), 173. https://doi.org/10.24042/djm.v1i2.2389

Sawilowsky, S. S. (2009). New Effect Size Rules of Thumb. Journal of Modern $\begin{array}{llll}\text { Applied Statistical } & \text { Methods, } & \text { 597-599. }\end{array}$ https://doi.org/10.22237/jmasm/1257035100

Thalheimer, W., \& Cook, S. (2002). How to calculate effect sizes from published research. Work-Learning Research, August, 1-9.

Ulya, M. R., Isnarto, Rochmad, \& Wardono. (2019). Efektivitas Pembelajaran Flipped Classroom dengan Pendekatan Matematika Realistik Indonesia terhadap Kemampuan Representasi Ditinjau dari Self-Efficacy. Jurnal PRISMA, 2, 116-123.

Unal, A., Unal, Z., \& Bodur, Y. (2021). Using Flipped Classroom in Middle Schools: Teachers' Perceptions. Journal of Research in Education, 30(2), 90112.

Veres, S., \& Muntean, A. D. (2021). THE FLIPPED CLASSROOM AS AN INSTRUCTIONAL MODEL. Romanian Review of Geographical Education, 10(1), 56-67. https://doi.org/10.1080/10511970.2015.1057786

Xiao, N., Thor, D., \& Zheng, M. (2021). Student preferences impact outcome of flipped classroom in dental education: Students favoring flipped classroom benefited more. Education Sciences, 11(4), 1-11. https://doi.org/10.3390/educsci11040150

Yanah, P. A., Nyeneng, I. D. P., \& Suana, W. (2018). Efektivitas Model Flipped Classroom pada Pembelajaran Fisika Ditinjau dari Self Efficacy dan Penguasaan Konsep Siswa. JIPFRI (Jurnal Inovasi Pendidikan Fisika Dan Riset Ilmiah), 2(2), 65-74. https://doi.org/10.30599/jipfri.v2i2.302

Yasar Kazu, İ., \& Kurtoğlu, C. (2020). Research of Flipped Classroom based on Students' Perceptions. Asian Journal of Education and Training, 6(3), 505-513. https://doi.org/10.20448/journal.522.2020.63.505.513

Zhang, F., \& Feng, S. (2019). Teaching Application of Micro-lesson and Flipped Classroom. Education Quarterly Reviews, 2(3), 480-486. https://doi.org/10.31014/aior.1993.02.03.80

Conflict of InterestStatement:The authors declare that theresearchwas conducted in the absence of any commercial or financial relationships that could be construed as a potential conflict of interest.

Copyright@2021Siti Ida Ermiana, Awal Nur Khalifatur Rosyidah, Asri Fauzi, Vivi Rachmatul Hidayati.This is anopen-accessarticledis- tributed under the terms of the Creative Commons Attribution License (CC BY). The use, distribution or reproduction in other forums is permitted, provided the original author(s) and the copyright owner(s) are credited and that the original publication in this journal is cited, in accordance with accepted academic practice. No use, distribu- tion or reproduction is permitted which does not comply with these terms. 


\section{LIST OF TABLE}

1 Hasil Uji Normalitas...

2 Hasil Uji Wilcoxon (Bag. 2). 
TABLE 1/Hasil Uji Normalitas

No. Nilai

$1 . \quad$ Pre-Test

2 df

32

32
Sig.

0.263

0.001
Kesimpulan

Data berdistribusi normal

Data berdistribusi tidak normal 
TABLE 2/Hasil Uji Wilcoxon (Bag. 2)

Wilcoxon Signed Ranks Test

Asymp. Sig. (2-tailed)

0.000 


\section{LIST OF FIGURE}

1 Desain One Group Pretest Postest ... 


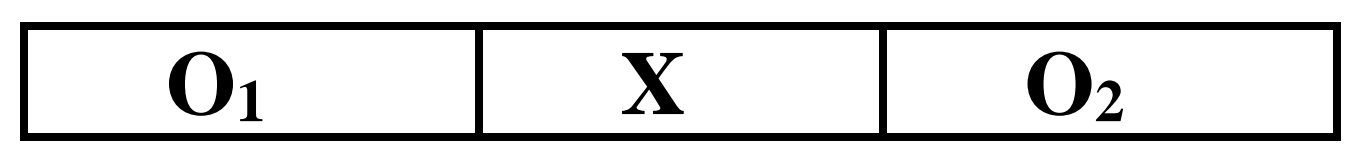

FIGURE 1 / Desain One Group Pretest Postest 